\title{
KUALITAS AIR SUMUR MASYARAKAT DI SEKITAR TEMPAT PEMBUANGAN AKHIR SAMPAH (TPAS) RAWA KUCING KOTA TANGERANG
}

\author{
Wahyuni*, Supriyono Eko Wardoyo, dan Ridha Arizal \\ Fakultas MIPA, Universitas Nusa Bangsa \\ Jl. K.H. Sholeh Iskandar, Cimanggu, Tanah Sareal-Bogor 16166 \\ *e-mail: why.yuni01@ gmail.com
}

\begin{abstract}
The Quality of Well Water around Final Garbage Dump (FGD) Rawa Kucing, Tangerang, Indonesia

FGD Rawa Kucing is located at Sultan Iskandar Muda Street, Kedaung Wetan, Neglasari, Tangerang, Banten, Indonesia. It serves 1000 tons of garbage per day from 13 districts in Tangerang. The volume of garbage in Kota Tangerang increases from 1,212,264 $\mathrm{m}^{3}$ in 2008 to 4,590,724 $\mathrm{m}^{3}$ in 2012. Well water is the main source of water for people around the FGD RawaKucing. They use well water for bath, wash, and toilet (BWT) and other needs. Garbage decomposition which makes pollution around FGD Rawa Kucing can accur in air, water, and soil. Waste accurs in water and soil caused by leachate. Leachate can easily spread through rainwater runoff and it absorbs to the ground and polluting it including well water around it. Contaminated well water can decrease the quality of water physically, chemically, and microbiologically.Groundwater samples taken from residents' well water around FGD Rawa Kucing and they were represented by three groups which have distance $100 \mathrm{~m}-3 \mathrm{~km}$ from FGD. Each group consisted of three samples which were taken from well water having depths between 8-18 $\mathrm{m}$. The examination of the quality of well water should be made in accordance with the Regulation of the Minister of Health of the Republic of Indonesia No.416/MENKE /PER/IX/1990 on the Conditions and Control of the Quality of Clean Water and Quality Regulation of the Minister of Health of the Republic of Indonesia No. 492/MENKES/PER/IV/ on Requirements and Quality Control of Drinking Water.The quality of well water around FGD Rawa Kucing showed that there were the decreased quality water after testing with several parameter tests. There were six examination parameters which concentrate on exceeding the required quality standards that of TDS (1600-1764 mg/L), Nitrates (10.5-37.8 mg/L), Ammonia (3.50-66.21 mg/L), Iron (1.054-7.063 mg/L), Manganese (1.085-10.130 mg/L), and Total Coliform (80-130 colonies $100 \mathrm{~mL}$ ).
\end{abstract}

Keywords : Well water, leachate, TPAS, pollution, water quality

\begin{abstract}
ABSTRAK
TPAS Rawa Kucing berada di Jalan Sultan Iskandar Muda Kelurahan Kedaung Wetan, Kecamatan Neglasari, Kota Tangerang, Banten dan mengangkut 1000 ton sampah/hari dari 13 kecamatan. Volume sampah di Kota Tangerang terus meningkat dari tahun 2008 sebesar $1.212 .264 \mathrm{~m}^{3}$ sampai pada tahun 2012 telah mencapai $4.590 .724 \mathrm{~m}^{3}$. Air sumur merupakan sumber air utama bagi masyarakat sekitar TPAS, karena hampir semua kebutuhan air dipenuhi dari air sumur yaitu untuk Mandi Cuci Kakus (MCK) dan kebutuhan lainnya. Pencemaran akibat dekomposisi sampah dapat terjadi di udara, dapat pula terjadi pada air dan tanah yang disebabkan oleh adanya rembesan air lindi. Lindi tersebut mudah disebarkan melalui limpasan air hujan dan meresap mencemari air tanah termasukair sumur yang ada di sekitarnya. Air sumur yang terkontaminasi lindi berakibat terjadinya penurunan kualitas air secara fisik, kimia, dan mikrobiologi. Air tanah sampelyang diambil berasal dari sumur penduduk yang berada di sekitar TPAS Rawa Kucing diwakili oleh 3 pengelompokkan dengan jarak $100 \mathrm{~m}-3 \mathrm{~km}$ dari TPAS. Setiap kelompok terdiri dari 3 sumur pompa dengan kedalaman sumur antara $8-18 \mathrm{~m}$. Pemeriksaan kualitas air sumur dilakukan mengacu pada Peraturan Menteri Kesehatan Republik Indonesia Nomor 416/MENKES/PER/IX/1990 tentang Syarat-syarat dan Pengawasan Kualitas Air Bersih dan Peraturan MenteriKesehatan Republik Indonesia Nomor 492/MENKES/PER/IV/2010 tentang Syarat-syaratdan Pengawasan Kualitas Air minum. Kualitas air sumur masyarakat di sekitar TPAS Rawa Kucing mengalami penurunan setelah dilakukan pengujian terhadap beberapa parameter. Ada 6 parameter pemeriksaan yang mempunyai konsentrasi melebihi baku mutu yang dipersyaratkan yaitu TDS (1600-1764 mg/L), Nitrat (10,5-37,8 mg/L), Amonia (3,50-66,21 mg/L), Besi (1,054-7,063 mg/L), Mangan (1,085-10,130 mg/L), dan Total Coliform (80-130 koloni/100 mL).
\end{abstract}

Kata kunci : Air sumur, air lindi, TPAS, pencemaran, kualitas air 


\section{PENDAHULUAN}

Penggunaan air tanah dengan sarana sumur bor dilakukan oleh penduduk di sekitar Tempat Pembuangan Akhir Sampah (TPAS). Air sumur merupakan sumber air utama bagi masyarakat sekitar TPAS, karena hampir semua kebutuhan air dipenuhi dari air sumur yaitu untuk Mandi Cuci Kakus (MCK) dan kebutuhan lainnya. TPAS merupakan tempat dimana sampah mencapai tahap terakhir dalam pengelolaannya sejak mulai timbul di sumber, pengumpulan, pemindahan/ pengangkutan, pengolahan dan pembuangan (Nur, 2015).

Sampah yang terbuka lebih dari 24 jam, mulai terjadi perombakan oleh mikroba, menghasilkan bahan-bahan organik berupa padatan terlarut bersifat toksik yang disebut lindi (leachate). Lindi tersebut mudah disebarkan melalui limpasan air hujan dan meresap mencemari air tanah termasuk air sumur yang ada di sekitarnya.

TPAS Rawa Kucing berdiri sejak tahun 1992 dan berada di Jalan Sultan Iskandar Muda, Kelurahan Kedaung Wetan, Kecamatan Neglasari Kota Tangerang, Banten, Indonesia dengan luas sekitar 34,8 hektar. Setiap hari, TPAS Rawa Kucing menerima puluhan truk sampah yang dikirim dari 13 kecamatan yang ada di kota Tangerang. Setiap armada truk mengangkut 3 ton sampah, dari 136 armada yang terdiri dari 126 truk dan 10 mobil kijang, mampu mengangkut rata-rata 1000 ton sampah setiap harinya.Volume sampah di Kota Tangerang terus meningkat dari tahun 2008 sebesar 1.212.264 $\mathrm{m}^{3}$ sampai pada tahun 2012 telah mencapai $4.590 .724 \mathrm{~m}^{3}$ (Pahlefi, 2014).

Parameter kualitas air sumur yang diukur adalah parameter fisika (suhu dan Total padatan terlarut/TDS), parameter kimia $(\mathrm{pH}$, ammonia, nitrat, nitrit, besi, mangan, tembaga, seng), dan parameter mikrobiologi (Coliform). Uji kualitas air ini mengacu pada Permenkes Nomor 416/Menkes/Per/IX/1990, tanggal 3 September 1990 tentang Syarat-syarat dan Pengawasan Kualitas Air Bersih dan Peraturan Menteri Kesehatan Republik Indonesia tanggal 19 April 2010 nomor 492/MENKES/PER/IV/2010 tentang syarat- syarat dan Pengawasan Kualitas Air minum. Tujuan penelitian ini adalah untuk mengetahui kualitas fisik, kimia, dan mikrobiologi air sumur masyarakat sekitar TPAS Rawa Kucing untuk dibandingkan standart mutu sebagai air bersih dan air mium.

\section{METODE}

\section{Bahan dan Alat}

Bahan-bahan yang digunakan dalam penelitian ini terdiri dari sampel air sumur penduduk dekat TPAS Rawa Kucing, air destilasi, larutan buffer $\mathrm{pH}$ 4, 7 dan 9, larutan standar TDS $1382 \mathrm{mg} / \mathrm{L}$, larutan standar $\mathrm{NO}_{3} 1000 \mathrm{mg} / \mathrm{L}$ dan reagen NitraVer 5 Nitrate, larutan standar $\mathrm{NO}_{2} 1000 \mathrm{mg} / \mathrm{L}$ dan reagen NitriVer 2Nitrite, larutan standar $\mathrm{NH}_{3} 1000 \mathrm{mg} / \mathrm{L}$, reagen Ammonia Salicylate dan Ammonia Cyanurate. Untuk pengujian parameter logam ( $\mathrm{Fe}, \mathrm{Mn}, \mathrm{Cu}$ dan $\mathrm{Zn}$ ) adalah air destilasi, asam nitrat $\left(\mathrm{HNO}_{3}\right)$ pekat, larutan standar $\mathrm{Fe}, \mathrm{Mn}, \mathrm{Cu}, \mathrm{Zn} 1000$ $\mathrm{mg} / \mathrm{L}$ dan gas asetilene $\left(\mathrm{C}_{2} \mathrm{H}_{2}\right)$. Untuk analisa coliform diperlukan bahan air destilasi, media Lactose Broth (LB) dan Brillian Green Lactose Broth (BGLB).

Alat-alat yang digunakan dalam penelitian ini adalah termometer air raksa, pHmeter Mettler Toledo, TDS meter/Conductivitymeter Agilent Technologies 3200C, Spektrofotometer Uv/Vis HACH DR 5000, Spektrofotemeter Serapan Atom (SSA) Perkin Elmer, Lampu hollow katoda $\mathrm{Fe}, \mathrm{Mn}, \mathrm{Zn}, \mathrm{Cu}$, kertas saring 0,45 mikron, Bunsen, Biosafety Cabinet Biobase, Neraca Analitik Mettler Toledo dan peralatan gelas lainnya.

\section{Metode}

Penelitian dilakukan di kawasan TPAS Rawa Kucing, Tangerang. Air tanah yang diambil berasal dari sumur penduduk yang berada di sekitar TPAS Rawa Kucing kelurahan Kedaung Wetan, Kota Tangerang. Sampel air tanah yang di ambil diwakili oleh 3 pengelompokkan dengan jarak $100 \mathrm{~m}-3$ $\mathrm{km}$ dari TPAS. Setiap kelompok terdiri dari 3 sumur pompa dengan kedalaman sumur antara $8-18 \mathrm{~m}$. 
Kelompok pertama adalah sumur penduduk yang digali sebelum pembuatan TPAS, kelompok kedua adalah sumur penduduk yang digali sesudah pembuatan TPAS dan kelompok yang ketiga adalah sumur penduduk dengan jarak kurang lebih 3 kilometer dari TPAS (yang tidak terpengaruh limbah TPAS) sebagai kontrol (Tabel 1).
Pengambilan sampel dilakukan sebanyak 2 (dua) kali disetiap titik sampel dengan menggunakan botol sampling ukuran $1000 \mathrm{~mL}$ (untuk parameter fisika dan kimia) dan $250 \mathrm{~mL}$ (untuk parameter mikrobiologi). Waktu pengambilan sampel adalah pada pagi hari pukul 5.00-7.00 dan pada waktu siang hari pukul $11.00-13.00$.

Tabel 1. Lokasi Titik Pengambilan Sampel

\begin{tabular}{ccccc}
\hline $\begin{array}{c}\text { Kelompok } \\
\text { Pengambilan }\end{array}$ & $\begin{array}{c}\text { Titik } \\
\text { Pengambilan }\end{array}$ & Alamat & $\begin{array}{c}\text { Jarak dari } \\
\text { TPAS }\end{array}$ & $\begin{array}{c}\text { Kedalaman } \\
\text { Sumur (m) }\end{array}$ \\
\hline \multirow{2}{*}{1} & 1A & Ked. Wetan 05/04 & $100 \mathrm{~m}$ & 10 \\
& 1B & Ked. Baru 02/02 & $200 \mathrm{~m}$ & 8 \\
& 1C & Ked. Baru 02/02 & $300 \mathrm{~m}$ & 8 \\
2 & & & & \\
& 2A & Ked. Wetan 07/03 & $300 \mathrm{~m}$ & 8 \\
& 2B & Ked. Wetan 07/03 & $300 \mathrm{~m}$ & 8 \\
& 2C & Ked. Wetan 07/03 & $300 \mathrm{~m}$ & 8 \\
3 & & & $3 \mathrm{~km}$ & 9 \\
& 3A & Komp. Sitanala 03/09 & $3 \mathrm{~km}$ & 15 \\
& 3B & Komp. PU pengairan & $3 \mathrm{~km}$ & 18 \\
\hline
\end{tabular}

Keterangan :

Kelompok 1 = Sebelum pembuatan TPAS

Kelompok $2=$ Sesudah pembuatan TPAS

Kelompok 3 = Kontrol

Tabel 2. Koordinat dan Kedalaman Lokasi Sampel

\begin{tabular}{|c|c|c|c|c|}
\hline \multirow{2}{*}{$\begin{array}{c}\text { Kelompok } \\
\text { Pengambilan }\end{array}$} & \multirow{2}{*}{$\begin{array}{c}\text { Titik } \\
\text { Pengambilan }\end{array}$} & \multicolumn{2}{|c|}{ Koordinat } & \multirow{2}{*}{$\frac{\text { Ketinggian }}{(\mathrm{mdpl})}$} \\
\hline & & Garis Lintang & Garis Bujur & \\
\hline \multirow{3}{*}{1} & $1 \mathrm{~A}$ & $\mathrm{~S} 06^{\circ} 08.131^{\prime}$ & E $106^{\circ} 37.003^{\prime}$ & 36 \\
\hline & 1B & $\mathrm{S} 06^{\circ} 08.128^{\prime}$ & E $106^{\circ} 36.964^{\prime}$ & 36 \\
\hline & $1 \mathrm{C}$ & $\mathrm{S} 06^{\circ} 08.044^{\prime}$ & E $106^{\circ} 37.006^{\prime}$ & 36 \\
\hline \multirow{3}{*}{2} & $2 \mathrm{~A}$ & S $06^{\circ} 07.906^{\prime}$ & E $106^{\circ} 37.217^{\prime}$ & 35 \\
\hline & 2B & $\mathrm{S} 06^{\circ} 07.955^{\prime}$ & E $106^{\circ} 37.254^{\prime}$ & 35 \\
\hline & $2 \mathrm{C}$ & $\mathrm{S} 06^{\circ} 07.956^{\prime}$ & E $106^{\circ} 37.251^{\prime}$ & 34 \\
\hline \multirow{3}{*}{3} & $3 \mathrm{~A}$ & $\mathrm{~S} 06^{\circ} 09.443^{\prime}$ & E $106^{\circ} 38.198^{\prime}$ & 40 \\
\hline & $3 \mathrm{~B}$ & $\mathrm{~S} 06^{\circ} 09.669^{\prime}$ & E $106^{\circ} 37.638^{\prime}$ & 38 \\
\hline & $3 \mathrm{C}$ & $\mathrm{S} 06^{\circ} 09.667^{\prime}$ & E $106^{\circ} 37.642^{\prime}$ & 38 \\
\hline
\end{tabular}


Parameter yang langsung diukur di lapangan adalah $\mathrm{pH}$ dan temperatur. Sampel yang dibawa ke laboratorium diperiksa parameter kimia (ammonia, nitrat, nitrit, tembaga, seng, mangan dan besi) dan mikrobiologi (total coliform) dengan dilakukan prosedur pengawetan sampel terlebih dahulu untuk pemeriksaan parameter kimia.

Metode analisis yang digunakan untuk pemeriksaan TDS adalah dengan TDS meter; Analisis ammonia, nitrat dan nitrit dilakukan dengan metode spektrofotometri; total coliform dihitung dengan pembiakan tabung ganda (MPN); dan logam berat ( $\mathrm{Fe}$, $\mathrm{Mn}, \mathrm{Cu}$ dan $\mathrm{Zn}$ ) ditentukan dengan metode Spektofotometri Serapan Atom (SSA).

\section{Penentuan Suhu Berdasarkan SNI 06.6989.23-2005}

Contoh uji diukur suhunya dengan cara memasukkan termometer air raksa ke dalam contoh uji dan diamkan 2 -5 menit sampai sampai termometer menunjukkan nilai yang stabil. Pembacaan skala dilakukan dengan cara melihat angka pada alat tanpa mengangkat lebih dahulu termometer dari air. Skala yang terbaca $t^{\circ} \mathrm{C}$.

\section{Penentuan pH berdasarkan SNI 06.6989.11-2004}

Sebelum menganalisis contoh dilakukan kalibrasi pHmeter dengan menggunakan larutan buffer $\mathrm{pH}$ 4, 7 dan 9 . Selanjutnya adalah memasukkan elektroda $\mathrm{pH}$ ke dalam gelas piala $250 \mathrm{~mL}$ yang berisi sampel, diukur pHnya dan dicatat.

\section{Penentuan Total Padatan Terlarut (TDS) sesuai TDS meter Handbook}

Langkah pertama yang dilakukan yaitu kalibrasi TDS meter dengan menggunakan larutan standar $1382 \mathrm{mg} / \mathrm{L}$. Selanjutnya dilakukan analisa contoh uji dengan memasukkan elektroda ke dalam gelas piala $250 \mathrm{~mL}$ yang berisi sampel, lalu diukur TDSnya dan dicatat.

\section{Penentuan Nitrat Sesuai Metode Reduksi Cadmium}

Pengujian contoh dilakukan dengan cara memasukkan $10 \mathrm{~mL}$ sampel air kedalam botol kemudian di tambahkan reagen NitraVer 5 Nitrate, dikocok selama 1 menit dan diinkubasi selama 5 menit. Contoh uji kemudian dianalisis menggunakan spektrofotometer Uv-Vis pada panjang gelombang $500 \mathrm{~nm}$. Botol blanko dimasukkan dan bacaan pada alat diset pada angka nol. Setelah itu, botol blanko digantikan larutan sampel, dibaca konsentrasi nitrat dalam $\mathrm{mg} / \mathrm{L}$ dan di catat.

\section{Penentuan Nitrit Sesuai Metode Diazotisasi}

Pengujian contoh dilakukan dengan cara memasukkan $10 \mathrm{~mL}$ sampel air ke dalam botol kemudian ditambahkan reagen NitriVer 3 Nitrite, dikocok lalu dinkubasi selama 20 menit, kemudian dianalisis menggunakan spektrofotometer $\mathrm{Uv}$-Vis pada panjang gelombang $507 \mathrm{~nm}$. Botol blanko dimasukkan dan bacaan pada alat diset pada angka nol. Setelah itu, botol blanko digantikan larutan sampel, dibaca konsentrasi nitrit dalam $\mathrm{mg} / \mathrm{L}$ dan di catat.

Penentuan ammonia sesuai metode salicylate

Pengujian contoh dilakukan dengan cara memasukkan $5 \mathrm{~mL}$ sampel air kedalam botol kemudian di tambahkan reagen Ammonia Salicylate, dikocok dan diinkubasi selama 3 menit, lalu ditambahkan lagi reagen Ammonia Cyanurate, dikocok dan inkubasi 15 menit, kemudian dianalisis menggunakan spektrofotometer Uv-Vis pada panjang gelombang $655 \mathrm{~nm}$. Botol blanko dimasukkan dan bacaan pada alat diset pada angka nol. Setelah itu, botol blanko digantikan larutan sampel, kemudian konsentrasi sampel dibaca dalam $\mathrm{mg} / \mathrm{L}$ dan dicatat.

\section{Penentuan besi (Fe) SNI.6989.4-2009}

Pengujian contoh dilakukan dengan cara dilakukan penyaringan sampel dengan kertas saring 0,45 mikron lalu dilakukan pengawetan dengan asam nitrat pekat. Setelah itu dilakukan pengukuran dengan Spektrofotometer Serapan Atom (SSA) pada panjang gelombang $248,3 \mathrm{~nm}$, dicatat konsentrasi dalam $\mathrm{mg} / \mathrm{L}$. 
Penentuan mangan (Mn) SNI.6989.5-2009

Pengujian contoh dilakukan dengan cara dilakukan penyaringan sampel dengan kertas saring 0,45 mikron lalu dilakukan pengawetan dengan asam nitrat pekat. Setelah itu dilakukan pengukuran dengan Spektrofotometer Serapan Atom (SSA) pada panjang gelombang $279,5 \mathrm{~nm}$, dicatat konsentrasi dalam $\mathrm{mg} / \mathrm{L}$.

\section{Penentuan seng (Zn) sesuai SNI.6989.7- 2009}

Pengujian contoh dilakukan dengan cara dilakukan penyaringan sampel dengan kertas saring 0,45 mikron lalu dilakukan pengawetan dengan asam nitrat pekat. Setelah itu dilakukan pengukuran dengan Spektrofotometer Serapan Atom (SSA) pada panjang gelombang 213,9 $\mathrm{nm}$, dicatat konsentrasi dalam $\mathrm{mg} / \mathrm{L}$.

\section{Penentuan tembaga (Cu) SNI.6989.6-2009}

Pengujian contoh dilakukan dengan cara dilakukan penyaringan sampel dengan kertas saring 0,45 mikron lalu dilakukan pengawetan dengan asam nitrat pekat. Setelah itu dilakukan pengukuran dengan Spektrofotometer Serapan Atom (SSA) pada panjang gelombang $324,7 \mathrm{~nm}$, dicatat konsentrasi dalam $\mathrm{mg} / \mathrm{L}$.

Penentuan coliform dengan metode MPN (Most Probably Number) SNI9308-1:2010

a. Tes Pendugaan (Presumptive Test)

Lima tabung masing-masing berisi Lactose Broth (LB) Double Strenght sebanyak $10 \mathrm{~mL}$ (tabung 1a s/d 5a). Lima tabung yang masing-masing berisi $5 \mathrm{~mL}$ Lactose Broth (LB) Single Strenght (tabung $1 \mathrm{~b}$ s/d 10b). Masing-masing $10 \mathrm{~mL}$ contoh uji diinokulasikan ke dalam tabung 1a s/d 5a; masing-masing $1 \mathrm{~mL}$ contoh uji ke dalam tabung $1 \mathrm{~b}-5 \mathrm{~b}$ dan masing-masing 0,1 $\mathrm{mL}$ contoh uji ke dalam tabung 6b-10b dengan menggunakan pipet steril. Masingmasing tabung dikocok perlahan agar sampel air merata menyebar ke seluruh bagian media, lalu inkubasi pada suhu $37{ }^{\circ} \mathrm{C}$ selama $2 \times 24$ jam, dan diamati masingmasing tabung untuk melihat ada atau tidaknya gas. Tes pendugaan yang positif di tandai dengan terbentuknya gas, tetapi hal ini belum memastikan adanya Colifecal di dalam air karena lactose broth dapat juga di fermentasikan oleh bakteri lain, selain Colifecal. Oleh sebab itu, tes pendugaan yang positif dilanjutkan dengan tes penegasan (Comfirmative test).

\section{b. Tes Penegasan (Comfirmative Test)}

Dari setiap tabung pendugaan yang positif, pindahkan 1-2 ose ke dalam tabung penegasan yang berisi $10 \mathrm{~mL}$ BGLB kemudian diinkubasi pada suhu $37^{\circ} \mathrm{C}$ selama 2x24 jam (untuk memastikan adanya E.coli). Pembacaan dilakukan dengan melihat jumlah tabung BGLB yang menunjukkan positif gas pada tabung urhamnya atau positif ber gas pada masing-masing tabung.

c. Langkah terakhir adalah menginterprestasikan hasil catatan jumlah tabung penegasan (tabung BGLB) yang menunjukkan positif gas. Angka yang diperoleh dicocokkan dengan tabel MPN Formula Thomas untuk mendapatkan indeks MPN per mL sampel air.

\section{HASIL DAN PEMBAHASAN}

Suhu

Metode pengukuran suhu dilakukan secara insitu atau dilakukan di lokasi pengambilan sampel. Data pengukuran suhu dari 3 kelompok pengambilan sampel bisa dilihat dari Gambar 1.

Berdasarkan Permenkes No. 416 Tahun 1990 tentang baku mutu dan kriteria pemeriksaan air bersih, suhu merupakan salah satu parameter fisik kualitas air yang memiliki nilai baku mutu deviasi $3^{\circ} \mathrm{C}$ dari suhu alamiahnya. Perbedaan suhu disebabkan karena pengaruh angin, kondisi kelembapan lingkungan sekitar, dan faktor cuaca (Komala et al., 2008). 


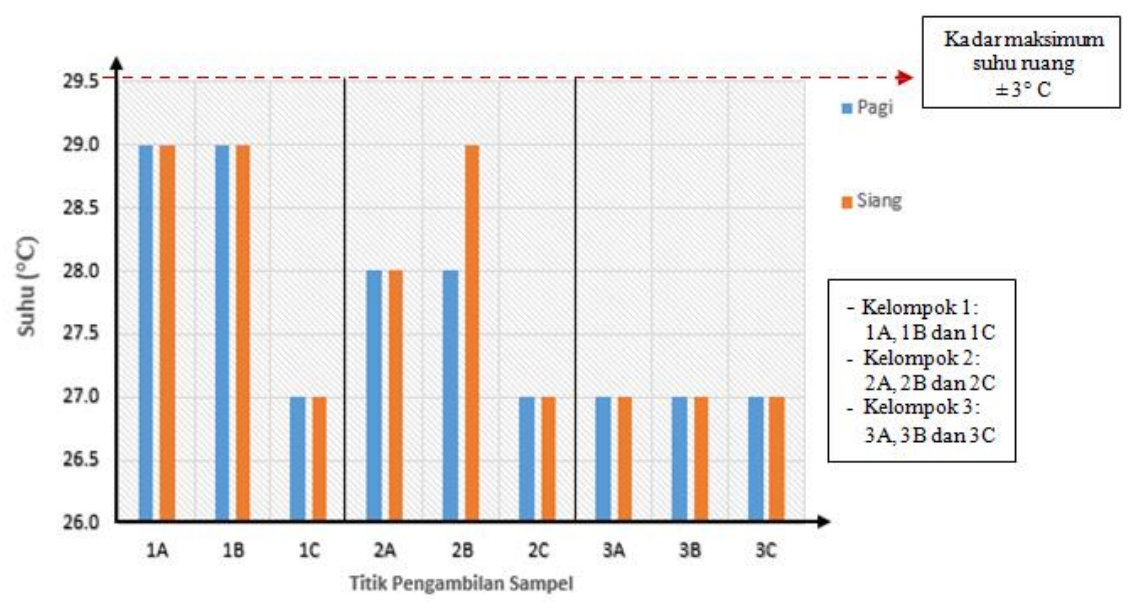

Gambar 1. Grafik Hubungan Suhu dengan Titik Pengambilan Sampel

Suhu dalam air tidak berpengaruh langsung terhadap kualitas air apabila air tersebut dikonsumsi ataupun digunakan dalam kehidupan sehari-hari. Namun tinggi dan rendahnya suhu akan berpengaruh terhadap reaksi kimiawi terhadap material yang terkandung di dalam air tersebut seperti logam besi maupun mangan. Nilai suhu dalam air yang terlalu tinggi di atas suhu lingkungan sekitar dapat dijadikan sebagai indikator pencemaran kualitas air tersebu.

\section{Total padatan terlarut (TDS)}

Total padatan terlarut terdiri dari senyawa-senyawa organik dan anorganik yang terlarut dalam air, mineral dan garamgaramnya (Soemirat, 2009 dalam Fajarini, 2014). Peraturan Menteri Kesehatan Republik Indonesia Nomor 416/Menkes/Per/IX/1990 memberikan batas maksimum untuk TDS adalah $1500 \mathrm{mg} / \mathrm{L}$. Data hubungan konsentrasi TDS dengan titik pengambilan sampel bisa dilihat dari Gambar 2.

Berdasarkan penelitian, sampel air tanah dari kelompok satu memiliki nilai TDS tertinggi, yaitu $1764 \mathrm{mg} / \mathrm{L}$, kemudian titik 2B dari kelompok kedua juga memiliki nilai TDS melebihi kadar maksimum yang dipersyaratkan yaitu 1600-1643 mg/L.
Konsentrasi TDS di sumur penduduk yang di gali sebelum pembuatan TPAS maupun sesudah pembuatan TPAS dengan rentang jarak yang hampir sama dari TPAS yaitu antara 100-300 m, masih cenderung tinggi walaupun rata-rata masih di bawah kadar maksimum yang dipersyaratkan. Penurunan konsentrasi TDS yang signifikan terjadi pada sampel yang diambil dengan jarak 3 km dari TPAS.

Konsentrasi TDS yang tinggi pada air tanah penduduk sekitar TPAS disebabkan oleh tingginya akumulasi hasil dekomposisi sampah organik dan anorganik yang ditimbun di TPA sampah Rawa Kucing. Hasil dekomposisi sampah ini yang menghasilkan air lindi dan bersama limpahan air hujan masuk/merembes ke sumur penduduk sekitar TPAS. Penyebab lain mungkin karena air buangan yang berasal dari air buangan rumah tangga dan industri yang mengandung molekul sabun, detergen dan surfaktan yang larut dalam air.

pH

Secara umum, air tanah mempunyai $\mathrm{pH}$ 6,5-8. Air dengan $\mathrm{pH}$ tinggi (basa) mengakibatkan daya bunuh klor terhadap mikroba berkurang, dan sebaliknya air dengan $\mathrm{pH}$ rendah cenderung meningkatkan korosi dan meningkatkan kelarutan logam (Soemirat, 2009 dalam Fajarini, 2014). 


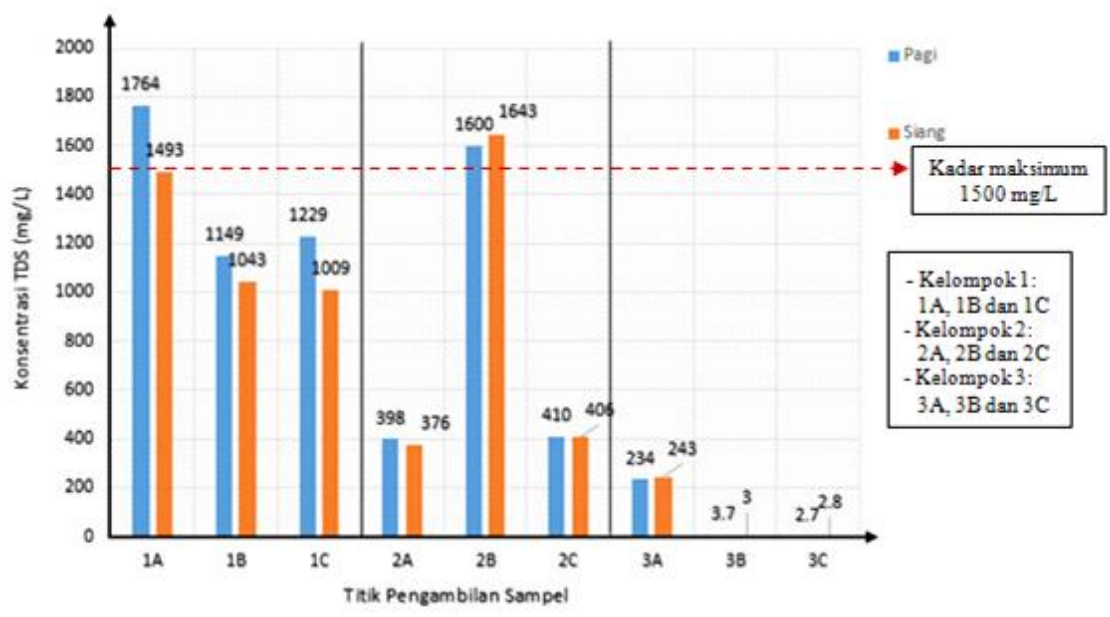

Gambar 2. Grafik Hubungan TDS dengan Titik Pengambilan Sampel

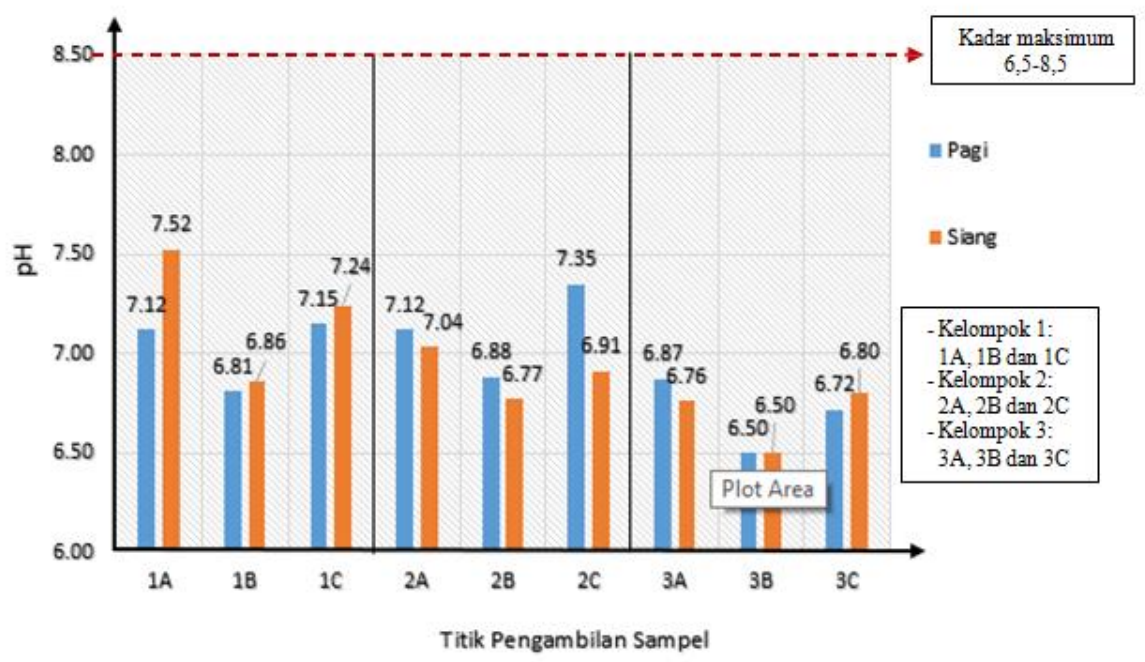

Gambar 3. Grafik Hubungan Nilai pH dengan Titik Pengambilan Sampel

Secara keseluruhan, nilai $\mathrm{pH}$ air tanah penduduk sekitar TPA Rawa Kucing masih berada dalam rentang $\mathrm{pH}$ netral yaitu 6,5-7,5. Peraturan Menteri Kesehatan Republik Indonesia Nomor 492/Menkes/Per/IV/2010 memberikan batas maksimum untuk parameter $\mathrm{pH}$ adalah 6,58,5 . Berdasarkan keterangan tersebut, sampel sumur air tanah berada dalam batas yang diperbolehkan untuk air bersih, walaupun pada beberapa sampel terjadi penurunan/kenaikan $\mathrm{pH}$ antara sampel yang diambil pagi dan siang hari (Gambar 3). Nilai $\mathrm{pH}$ yang cenderung rendah pada siang hari dipengaruhi reaksi fotosintesa pada tanaman, yaitu reaksi yang menyerap $\mathrm{CO}_{2}$ dan menghasilkan oksigen. Hal ini menyebabkan terjadinya peningkatan konsentrasi $\mathrm{CO}_{2}$ dalam air tanah. Konsentrasi $\mathrm{CO}_{2}$ ini berpengaruh terhadap tingkat keasaman karena berikatan dengan air membentuk $\mathrm{H}_{2} \mathrm{CO}_{3}$ yang membuat air bersifat asam. Air yang berikatan dengan $\mathrm{CO}_{2}$ akan masuk ke dalam sumur bersama dengan rembesan air lindi atau limpasan air hujan dan menyebabkan $\mathrm{pH}$ air sumur menjadi semakin rendah atau cenderung asam.

\section{Nitrat $\left(\mathrm{NO}_{3}\right)$}

Senyawa nitrit dapat dengan mudah dioksidasikan menjadi nitrat, maka nitrat adalah senyawa yang paling banyak ditemukan di dalam air bawah tanah atau air 
permukaan. Kadar nitrat secara alamiah biasanya rendah, namun kadar nitrat dapat menjadi tinggi sekali pada air tanah dengan bersumber dari kegiatan manusia seperti pembuangan limbah domestik, pelindihan TPAS dan penggunaan pupuk yang berlebihan (Alaerts, 1987). Grafik hubungan konsentrasi nitrat dengan titik pengambilan sampel bisa dilihat Gambar 4.

Konsentrasi nitrat di daerah penelitian berkisar antara $1,1 \mathrm{mg} / \mathrm{L}$ hingga $37,8 \mathrm{mg} / \mathrm{L}$. Peraturan Menteri Kesehatan Republik Indonesia Nomor 416/Menkes/Per/IX/1990 memberikan batas maksimum yang diperbolehkan untuk nitrat adalah $10 \mathrm{mg} / \mathrm{L}$.

Sampel sumur air tanah pada daerah sebelum pembuatan TPAS memiliki konsentrasi nitrat melebihi kadar maksimum dari yang dipersyaratkan untuk air bersih. Sedangkan pada daerah sesudah pembuatan TPAS konsentrasi nitrat lebih kecil daripada daerah sebelumnya. Konsentrasi nitrat yang berada di bawah kadar maksimum yang dipersyaratkan diperoleh dari sampel air tanah yang berasal dari daerah dengan jarak kurang lebih $3 \mathrm{~km}$ dari TPAS.

Konsentrasi nitrat yang tinggi pada air ini disebabkan oleh proses oksidasi secara sempurna pada senyawa nitrogen dari dalam sampah yang banyak mengandung bahan organik. Hal ini juga mungkin dipengaruhi oleh sifat nitrat yang sangat mudah larut dalam air dan bersifat stabil (Sudaryanto \& Suherman, 2008).

\section{Nitrit $\left(\mathrm{NO}_{2}\right)$}

Nitrit merupakan bentuk nitrogen yang teroksidasi dengan tingkat oksidasi +3 . Nitrit biasanya tidak bertahan lama dan biasanya merupakan keadaan sementara proses oksidasi antara amonia dan nitrat, yang dapat terjadi pada instalasi pengolahan air buangan, dalam air sungai dan sistem drainase (Alaerts, 1987).

\begin{tabular}{lrr}
\multicolumn{1}{c}{ Peraturan Menteri } & Kesehatan \\
Republik & Indonesia & Nomor \\
416/Menkes/Per/IX/1990 & tentang
\end{tabular}

Persyaratan Kualitas Air memberikan batas maksimum untuk nitrit $1,0 \mathrm{mg} / \mathrm{L}$. Secara umum, konsentrasi nitrit pada sampel hasil penelitian masih berada pada konsentrasi di bawah kadar maksimum yang dipersyaratkan. Kadar nitrit pada perairan relatif kecil karena segera dioksidasi menjadi nitrat (Alaerts, 1987).Konsentrasi nitrit lebih tinggi pada sampel air sumur penduduk sebelum pembuatan TPAS, hal ini dikarenakan konsentrasi nitrat dan ammonia yang tinggi pada sampel yang sama (Gambar 5).

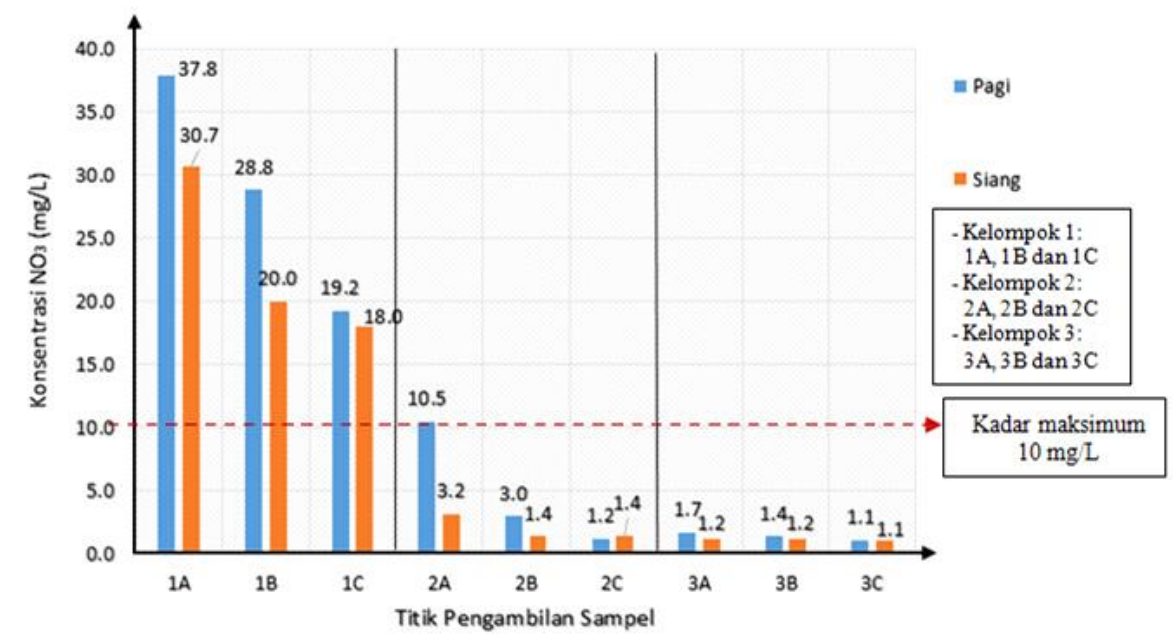

Gambar 4. Grafik Hubungan Konsentrasi Nitrat dengan Titik Pengambilan Sampel 


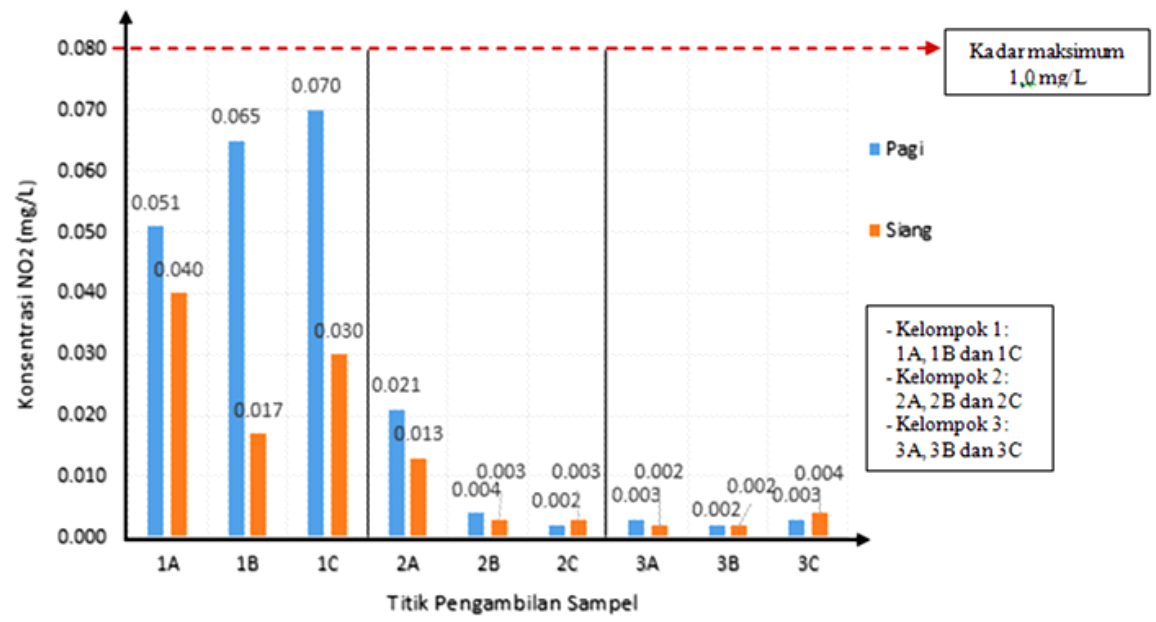

Gambar 5. Grafik Hubungan Konsentrasi Nitrit dengan Titik Pengambilan Sampel

\section{Ammonia $\left(\mathrm{NH}_{3}-\mathrm{N}\right)$}

Amoniak dalam air permukaan berasal dari air seni dan tinja, juga dari oksidasi zat organik $\left(\mathrm{H}_{\mathrm{a}} \mathrm{O}_{\mathrm{b}} \mathrm{C}_{\mathrm{c}} \mathrm{N}_{\mathrm{d}}\right)$ secara mikrobiologis yang berasal dari air alam atau air buangan industri dan penduduk (Alaerts, 1987). Grafik hubungan konsentrasi ammonia dengan titik pengambilan sampel dapat dilihat dari Gambar 6.

$$
\begin{array}{ccr}
\text { Peraturan } & \begin{array}{c}
\text { Menteri } \\
\text { Republik }
\end{array} \text { Indonesia } & \text { Nomor }
\end{array}
$$

492/Menkes/Per/IV/2010 memberikan batas maksimum untuk amoniak $1,5 \mathrm{mg} / \mathrm{L}$. Berdasarkan Gambar 6, sampel sumur air tanah di kelompok 1 dan 2 memiliki konsentrasi ammonia melebihi kadar maksimum yang dipersyaratkan yaitu antara 3,5-66,21 mg/L.

Konsentrasi amonia yang tinggi ini mungkin disebabkan jarak sumur dari kedua kelompok yang dekat dengan TPAS (0-300 $\mathrm{m})$. Air sumur tercemar oleh rembesan air dari hasil pembusukan sampah disekitarnya. Pada sumur penduduk di kelompok 3 memiliki konsentrasi ammonia di bawah kadar maksimum yang dipersyaratkan, hal ini disebabkan jarak sumur $\pm 3 \mathrm{~km}$ dari TPAS sehingga pengaruh air lindi terhadap air sumur sudah tidak ada.

Sumber utama amonia adalah adanya bahan organik hasil penguraian sampah oleh bakteri yang tidak dapat teroksidasi menjadi nitrit dan nitrat sehingga bersama-sama air hujan senyawa amonia akan terangkut dan meresap ke dalam air tanah dangkal.Selama proses penguraian mikrobiologis, zat organis tersebut melepaskan nitrogen sebagai amoniak $\left(\mathrm{NH}_{3}\right)$ atau senyawa yang lebih rumit mirip amoniak (yaitu amin $\mathrm{R}^{-\mathrm{NH}_{2}}$, RR'-NH dan sebagainya) (Alaerts, 1987).

\section{Besi (Fe)}

Besi terkandung dalam tanah, sedimen, dan air bersih dalam bentuk tidak terlarut yaitu ferric oksida dan sulfida (pyrite). Di dalam air besi hadir dalam dua bentuk, yakni besi ferrous dengan sifat mudah larut dan besi ferric dengan sifat sukar larut. Dikarenakan air bersih biasanya mengandung sejumlah $\mathrm{CO}_{2}$, maka ferrous karbonat yang terlarut dalam air bersih dapat diakibatkan karena reaksi sebagai berikut (Sawyer, 2003 dan Adipura, 2015):

$\mathrm{FeCO}_{3}(\mathrm{~s})+\mathrm{CO}_{2}+\mathrm{H}_{2} \mathrm{O} \rightarrow \mathrm{Fe}^{2+}+2 \mathrm{HCO}_{3}^{-}$

Peraturan Menteri Kesehatan Republik Indonesia Nomor 416/Menkes/ Per/IX/1990 tentang Persyaratan Kualitas Air memberikan batas maksimum untuk besi1,0 mg/L. Grafik hubungan konsentrasi besi dengan titik pengambilan sampel bisa dilihat pada Gambar 7. 


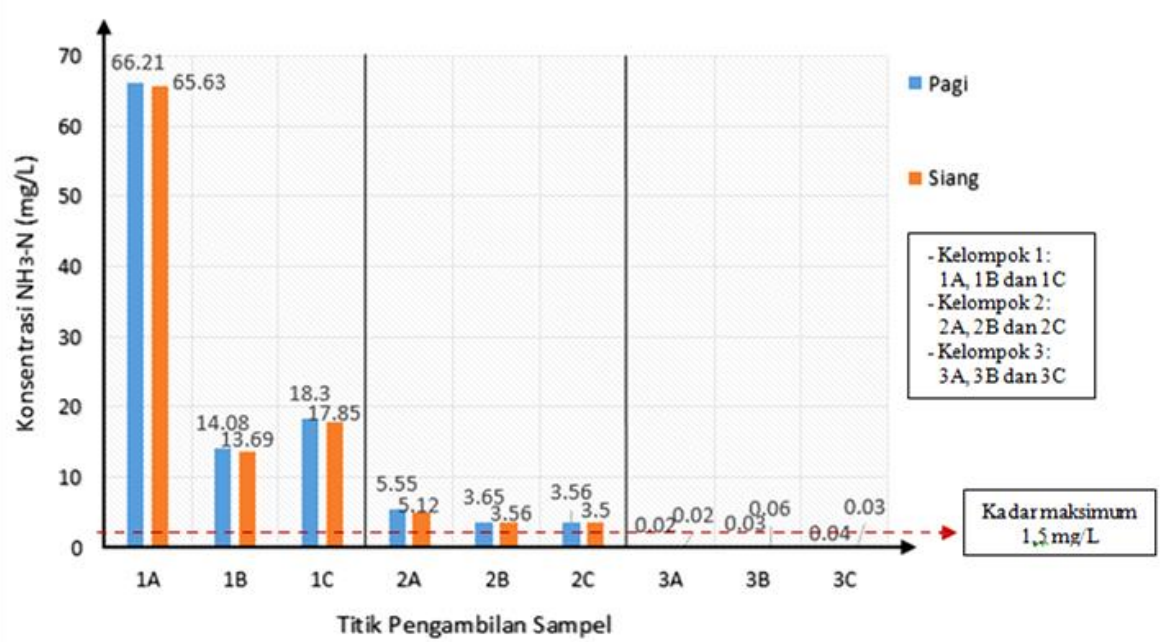

Gambar 6. Grafik Hubungan Konsentrasi Ammonia dengan Titik Pengambilan Sampel

Berdasarkan hasil penelitian, konsentrasi besi pada sampel air sumur sebelum pembuatan TPA dan sesudah pembuatan TPA dengan rentang jarak yang hampir sama $(100-300 \mathrm{~m})$ dari TPA melebihi kadar maksimum yang dipersyaratkan. Konsentrasi besi yang memenuhi persyaratan air bersih terjadi pada sampel yang diambil dengan jarak $\pm 3 \mathrm{~km}$ dari TPA.

Beberapa penyebab tingginya konsentrasi besi pada air sumur karena pada air permukaan jarang ditemui kadar Fe lebih besar dari $1 \mathrm{mg} / \mathrm{L}$, tetapi dalam air tanah $\mathrm{Fe}$ dapat jauh lebih tinggi. Pada air yang tidak mengandung oksigen (anaerob) seperti air tanah, ion ferric $\left(\mathrm{Fe}^{3+}\right)$ akan berubah menjadi besi ferrous $\left(\mathrm{Fe}^{2+}\right)$ yang larut dalam air (Alaerts, 1987). Hal ini yang menyebabkan konsentrasi besi yang tinggi pada air sumur penduduk sekitar TPA.

\section{Mangan (Mn)}

Sumber mangan di lingkungan akibat aktivitas manusia adalah limpasan air limbah dari WWTP (Waste Water Treatment Plan), pengolahan lumpur, proses penambangan, emisi dari logam,produksi besi, pembakaran bahan bakar fosil dan juga emisi dari pembakaran zat aditif untuk bahan bakar (Erlina, 2012). Kondisi kimiawi lingkungan dari Peraturan Menteri Kesehatan Republik Indonesia Nomor 416/Menkes/Per/IX/1990 tentang Persyaratan Kualitas Air memberikan batas maksimum untuk mangan $0,5 \mathrm{mg} / \mathrm{L}$.

Berdasarkan hasil penelitian, terdapat konsentrasi mangan yang tinggi pada sampel air sumur penduduk sebelum pembuatan TPAS dan sesudah pembuatan TPAS sehingga melebihi kadar maksimum yang dipersyaratkan. Konsentrasi mangan yang sesuai dengan persyaratan air bersih diperoleh pada sampel air sumur dengan jarak $3 \mathrm{~km}$ dari TPAS. Hal ini terjadi karena mangan dalam kondisi aerob tipikal berbentuk $\mathrm{Mn}(\mathrm{IV}) \mathrm{O}_{2}$ yang sangat tidak larut, tapi dalam kondisi anaerob mangan akan menurunkan tingkatannya menjadi Mn (II) dengan sifat mudah larut (Gambar 8). 


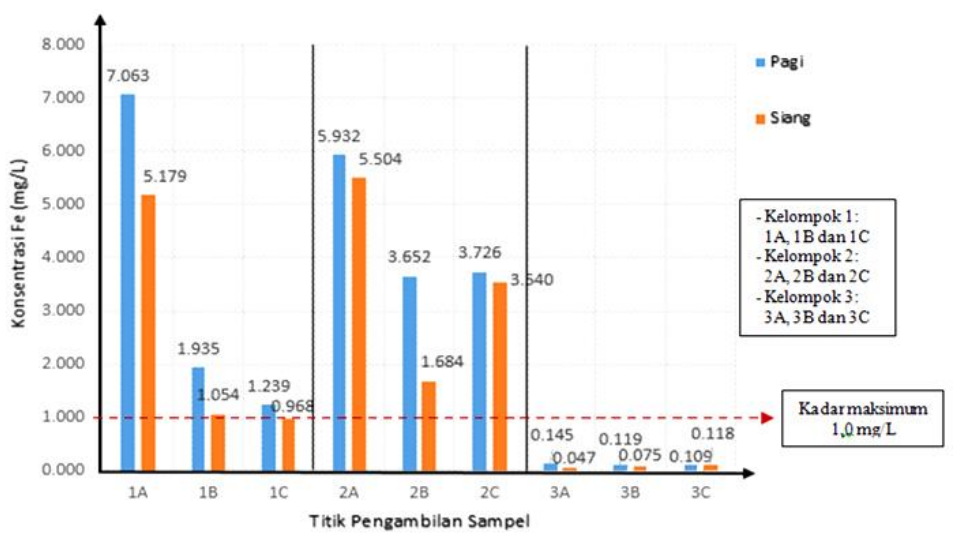

Gambar 7. Grafik Hubungan Konsentrasi Besi dengan Titik Pengambilan Sampel

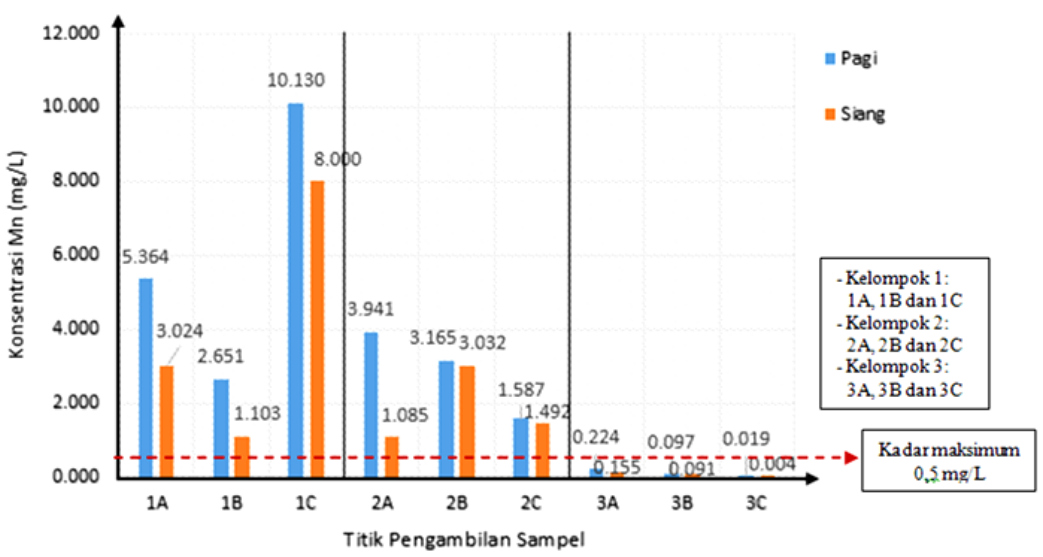

Gambar 8. Grafik Hubungan Konsentrasi Mangan dengan Titik Pengambilan Sampel

Faktor yang mempengaruhi tinggi rendahnya konsentrasi mangan dalam air bersih antara lain kandungan oksigen dalam air (DO), $\mathrm{pH}$, reaksi oksidasi dalam air dan mikroorganisme. Sebagian besar mikroorganisme membutuhkan oksigen dalam proses respirasinya (aerob) dan memecah material organik. Namun pada saat ketersediaan oksigen terbatas atau sedikit, beberapa bakteri dapat menggunakan alternatif lainnya seperti memanfaatkan nitrat, sulfat dan karbondioksida untuk melakukan respirasi (anaerob). Beberapa faktor yang mempengaruhi kehadiran mikroorganisme dalam air bersih antara lain ketersediaan nutrisi, pH, kandungan garam, suhu dan permeabilitas dari akuifer (Erlina, 2012). Kondisi bakteri anaerob yang bisa memanfaatkan nitrat yang tinggi dari air sumur dekat TPAS inilah yang memungkinkan terbentuknya Mn (II) yang larut dalam air.

\section{Seng (Zn)}

Seng adalah salah satu logam berat yang paling mudah bergerak pada air tanah. Ion seng mudah terserap ke dalam sedimen dan tanah. Kadar seng dalam air sangat dipengaruhi oleh bentuk senyawanya.

Berdasarkan Gambar 9, konsentrasi $\mathrm{Zn}$ pada air sumur penduduk di sekitar TPAS Rawa Kucing berada di bawah kadar maksimum yang dipersyaratkan. Peraturan Menteri Kesehatan Republik Indonesia Nomor 416/Menkes/Per/IX/1990 tentang Persyaratan Kualitas Air memberikan batas maksimum untuk seng15 mg/L.Adsoprsi dari seng meningkat seiring dengan meningkatnya $\mathrm{pH}$ tanah. Pada $\mathrm{pH}$ 6-12 seng membentuk $\mathrm{ZnCO}_{3}$ dan $\mathrm{Zn}(\mathrm{OH})_{2}$ yang dapat mengontrol tingkat kelarutan sengserta akan 
terbentuk seng kembali dalam ion bebas. (Vogel, 1985).

\section{Tembaga (Cu)}

Unsur tembaga di alam dapat ditemukan dalam bentuk logam bebas (Palar, 1994). Cu banyak terdapat dalam air, tanah, dan udara baik dalam bentuk ion maupun persenyawaan. Peraturan Menteri Kesehatan Republik Indonesia Nomor 492/Menkes/Per/IV/2010 tentang Persyaratan Kualitas Air memberikan batas maksimum untuk $\mathrm{Cu} 2,0 \mathrm{mg} / \mathrm{L}$.
Berdasarkan Gambar 10, Air sumur masyarakat sekitar TPAS mengandung konsentrasi logam berat tembaga $(\mathrm{Cu})$ di bawah kadar maksimum yang dipersyaratkan. Konsentrasi tembaga yang tidak terdeteksipada beberapa air sumur diperkirakan karena tembaga dapat membentuk endapan $\mathrm{Cu}(\mathrm{OH})_{2}$ pada $\mathrm{pH}$ 6-8 (Vogel, 1985). Konsentrasi tembaga pada air tanah dipengaruhi oleh garam-garam tembaga, misalnya; tembaga karbonat $\left(\mathrm{CuCO}_{3}\right)$, tembaga hidroksida $\mathrm{Cu}(\mathrm{OH})_{2}$, dan tembaga sulfida $(\mathrm{CuS})$ bersifat tidak mudah larut dalam air (Effendi, 2003).

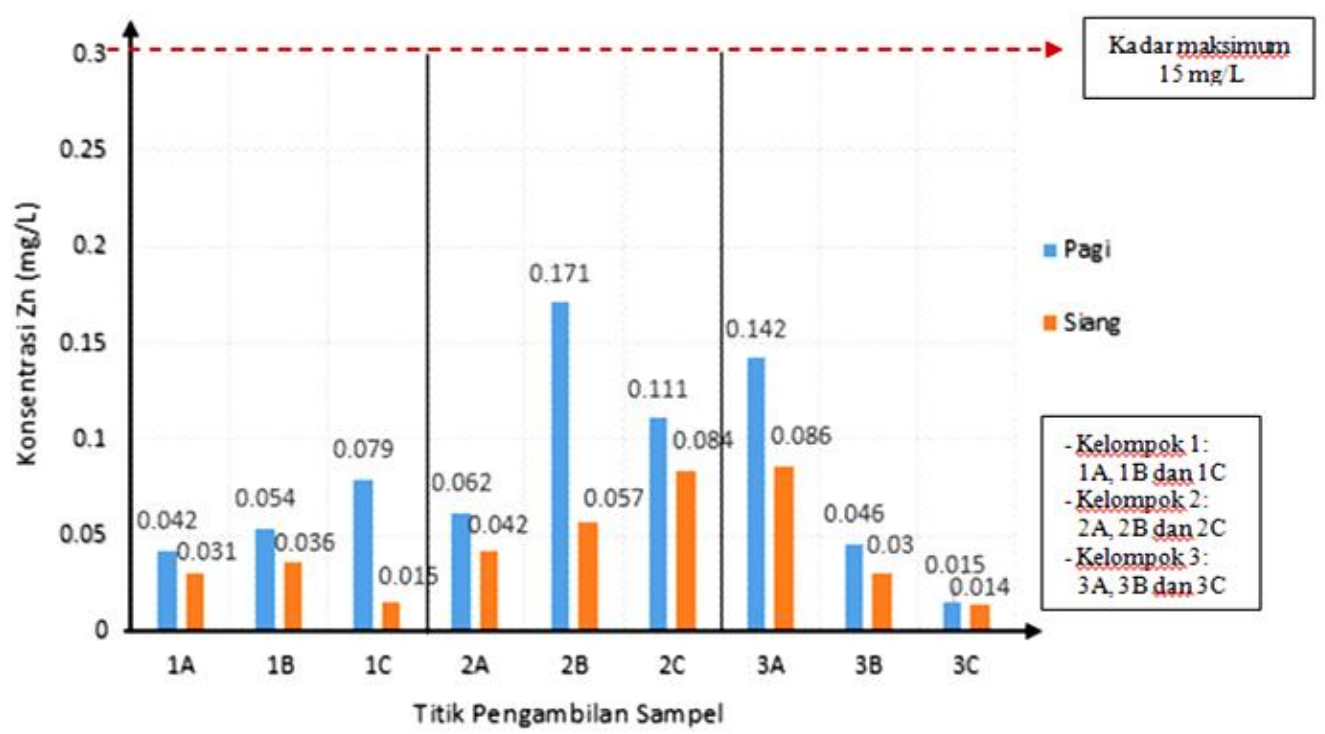

Gambar 9. Grafik Hubungan Konsentrasi Seng dengan Titik Pengambilan Sampel

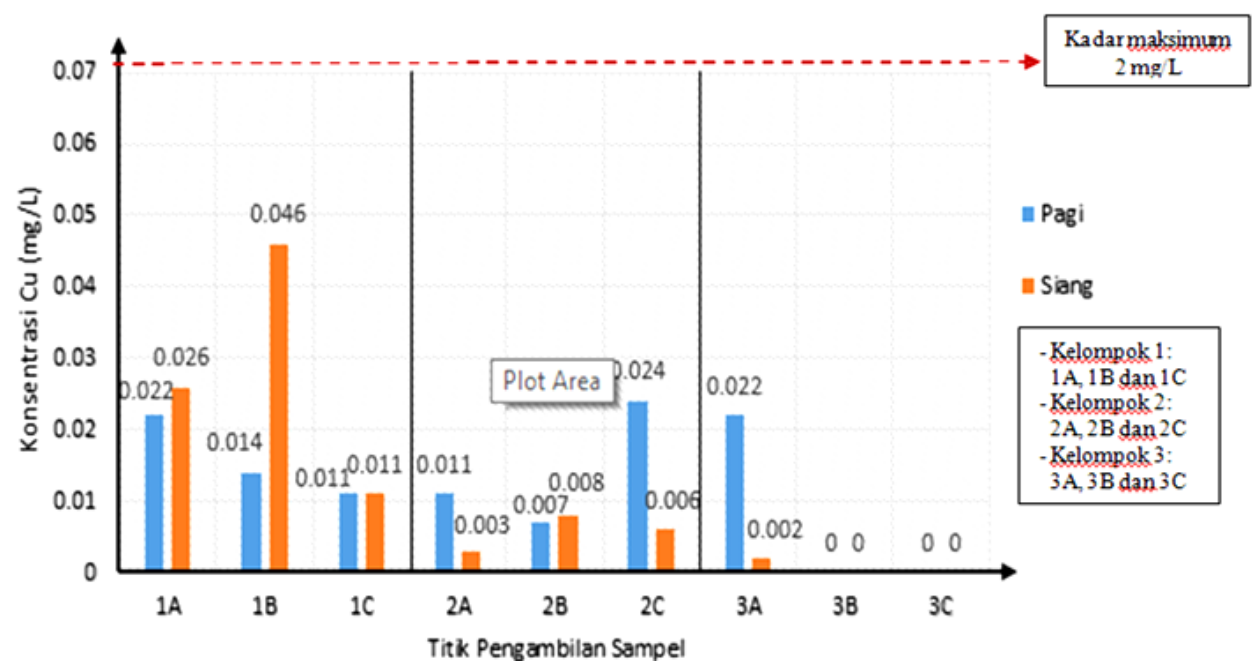

Gambar 10. Grafik Hubungan Konsentrasi Tembaga dengan Titik Pengambilan Sampel 


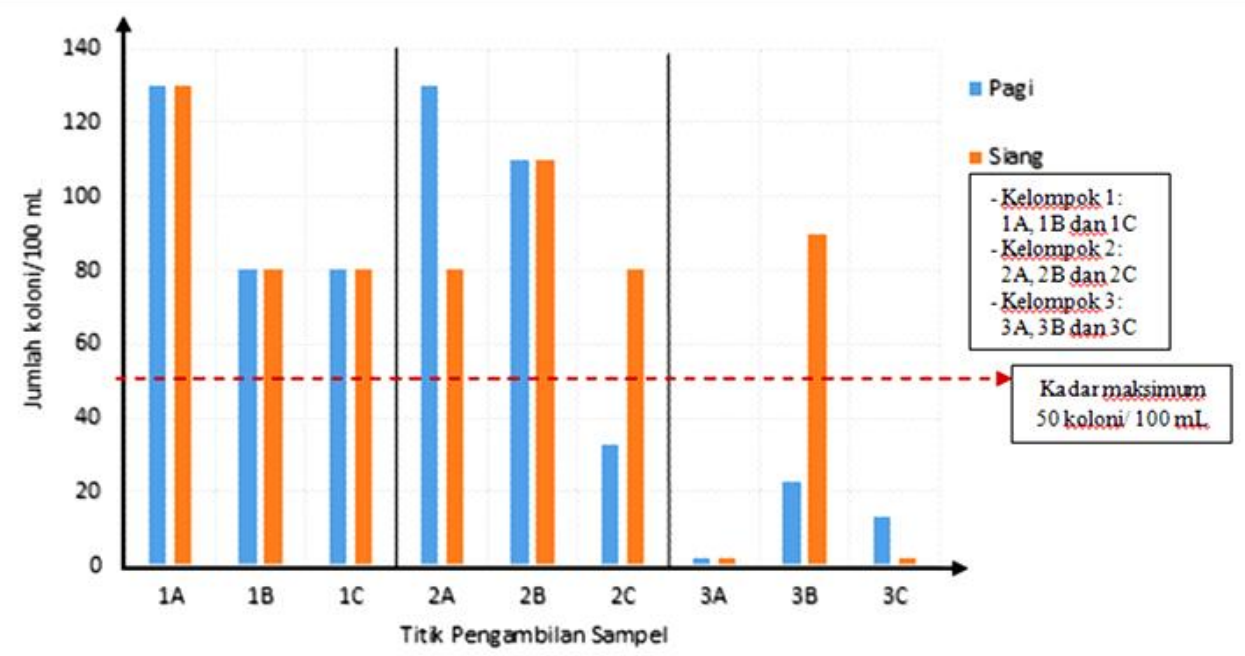

Gambar 11. Grafik hubungan Jumlah Bakteri dengan titik pengambilan sampel

\section{Total Coliform}

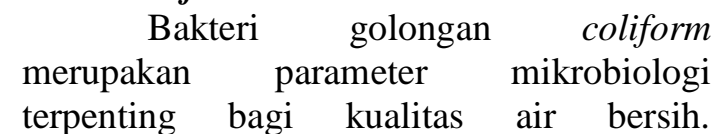
Keberadaan bakteri ini menunjukkan tingkat hygiene yang rendah yang membahayakan kesehatan (Budiarti et al, 2013).

\begin{tabular}{lrr}
\multicolumn{1}{c}{ Peraturan Menteri } & Kesehatan \\
Republik & Indonesia & Nomor \\
416/Menkes/Per/IX/1990 & tentang
\end{tabular}

Persyaratan Kualitas Air memberikan batas maksimum untuk coliform total adalah 50 MPN/100 mL. Pada Gambar 11, air sumur di kelompok 1 dan 2 kandungan total coliform yang tinggi. Kondisi ini mengindikasikan pada lokasi pengamatan lebih banyak sampah yang bersumber dari sisa-sisa tumbuhan, sisa-sisa makanan, dan bangkai-bangkai hewan, merupakan substrat utama tumbuhnya bakteri coliform. Bakteri ini bersama dengan air hujan dapat secara langsung atau meresap masuk ke lapisan tanah atas, dan akhirnya masuk dan terakumulasi dalam air sumur.

Sumber pencemar mikrobiologis dari sistem pembuangan sampah dapat meresap ke dalam air tanah secara vertikal maupun horizontal. Bouwer dan Chaney dalam Wuryadi (1981) menemukan bahwa bakteri dapat bergerak sejauh 830 meter dari sumber kontaminan.

\section{KESIMPULAN}

Berdasarkan hasil penelitian didapatkan kesimpulan :

1. Kualitas air sumur masyarakat di sekitar TPAS Rawa Kucing mengalami penurunan setelah dilakukan pengujian terhadap beberapa parameter.

2. Ada 6 parameter pemeriksaan yang mempunyai konsentrasi melebihi baku mutu yang dipersyaratkan yaitu TDS (1600-1764 mg/L), Nitrat (10,5-37,8 $\mathrm{mg} / \mathrm{L})$, Amonia (3,50-66,21 mg/L), Besi $(1,054-7,063 \mathrm{mg} / \mathrm{L})$, Mangan (1,085$10,130 \mathrm{mg} / \mathrm{L})$, dan Total Coliform (80130 koloni/100 mL).

3. Sumur penduduk yang berjarak $0-300$ paling dekat dengan TPAS Rawa Kucing memiliki kandungan zat pencemar paling banyak dan zat pencemar ini berkurang sampai dengan jarak terjauh yaitu $\geq 3$ $\mathrm{km}$.

4. Pada lokasi pengambilan air sumur yang digali sebelum pembuatan TPAS Rawa Kucing dan sesudah pembuatan TPAS tidak terdapat perbedaan signifikan. Hal ini karena jarak lokasi tidak berbeda jauh yaitu sekitar 100-300 m dan pengaruh rembesan air lindi dari TPAS ke sumur penduduk masih ada.

5. Pada titik pengambilan air sumur dengan jarak $3 \mathrm{~km}$ dari TPAS Rawa Kucing, konsentrasi pengukuran semua parameter bisa memenuhi persyaratan air bersih. Hal ini menandakan bahwa rembesan air 
lindi dari TPAS tidak ada pengaruh sama sekali terhadap air sumur tersebut.

6. Adanya aliran sungai Cisadane di sebelah timur TPAS Rawa Kucing diduga menyebabkan sebagian air lindi mengalir ke sungai tersebut.

\section{DAFTAR PUSTAKA}

Alaerts, G. dan S.S. Santika, 1987. Metode Penelitian Air. Usaha Nasional. Surabaya.

Arsadi, 2007. Optimalisasi Sumber Daya Air di wilayah Pesisir : Studi kasus: Pantai Utara Kabupaten Karawang, Jawa Barat. LIPI Press. Jakarta. Kumpulan Jurnal Sumber Daya Air dan Lingkungan, Potensi, Degradasi dan Masa Depan.

Budiarti, A., Rupmini dan H. R. Soenoko, 2013. Kajian Kualitas Air Sumur Sebagai Sumber Air Minum Di Kelurahan Gubug, Kecamatan Gubug, Kabupaten Grobogan. Fakultas Farmasi, Universitas Wahid Hasyim. Semarang. Jurnal Ilmu Farmasi dan Farmasi Klinik Volume 10 No 1 Juni 2013.

Chapman, D., 2000. Water Quality Assesment. E \& FN Spon. London.

Darmono, 2001. Lingkungan Hidup dan Pencemaran. UI Press. Jakarta

Effendi, H., 2003. Telaah Kualitas Air bagi Pengelolaan Sumber Daya dan Lingkungan Perairan, Penerbit Kanisius. Yogyakarta.

Erlina, A., 2012. Pengaruh Keberadaan TPA Cipayung Depok terhadap Kualitas Sumber Air Bersih di Wilayah Pemukiman Sekitarnya (Dengan Parameter Besi dan Mangan). Program Studi Teknik Lingkungan Fakultas Teknik, Universitas Indonesia. Depok.

Fajarini, S., 2014. Analisa Kualitas Air Tanah Masyarakat di sekitar
Tempat Pembuangan Akhir (TPA) Sampah di kelurahan Sumur Batu, Bantar Gebang Bekasi Tahun 2013. Fakultas Kedokteran dan Ilmu Kesehatan, Universitas Islam Negeri Syarif Hidayatullah. Jakarta.

Fardiaz, S., 1992. Polusi Air dan Udara. Kanisius. Yogyakarta.

Freeze, A. R., J.A. Cherry. 1979. Groundwater. Prentice-Hall, EnglewoodCliffs, NJ.

Ginting, P., 2007. Sistem Pengelolaan Lingkungan dan Limbah Industri. Cetakan pertama. Bandung.

Nur, F., 2015. Analisis Kualitas Air Tanah di Sekitar TPA Tamangapa dengan Parameter Biologi. Program Studi Teknik Lingkungan Jurusan teknik Sipil, Universitas Hasanuddin. Makasar. Jurnal Repository Unhas.

Palar, H., 1994. Pencemaran dan Toksikologi Logam Berat. PT. Rineka Cipta. Jakarta.

Pahlefi, R., 2014. Estimasi Nilai Eksternalitas dari Tempat Pemrosesan Akhir Sampah (Studi Kasus TPA Rawa Kucing Kota Tangerang). Departemen Ekonomi Sumberdaya dan Lingkungan. Fakultas Ekonomi dan Manajemen Institut Pertanian Bogor. Bogor.

Sudaryanto \& Suherman, 2008. Degradasi Kualitas Airtanah berdasarkan Kandungan Nitrat di Cekungan Air tanah Jakarta.Jakarta. Jurnal Riset Geologi dan Pertambangan Jilid 18 No.2 (2008).

Vogel,1985. Analisis Anorganik Kualitatif Makro dan Semi Mikro. Terjemahan Setiono dan Pudjaatmaka. PT Kalman Media Pusaka. Jakarta.

Wuryadi. 1981. Kualitas Air Sumur Gali DIY Bagian Selatan dan Kemungkinan Pengaruh Lingkungan 
Pemukiman. Fakultas Pascasarjana IPB. Bogor.

Permenkes Nomor 416/Menkes/Per/ IX/1990, Tanggal 3 September 1990 tentang Syarat-syarat dan Pengawasan Kualitas Air Bersih.
Peraturan Menteri Kesehatan Republik Indonesia Nomor 492/MENKES/ PER/IV/2010 tanggal 19 April 2010 tentang Syarat-syarat dan Pengawasan Kualitas Air Minum. 